University of New Hampshire

University of New Hampshire Scholars' Repository

Spring 2015

\title{
Estimating plasma volume in neonatal Holstein calves fed one or two feedings of a lacteal-based colostrum replacer using Evans blue dye and hematocrit values at various time points.
}

\author{
Peter S. Erickson \\ University of New Hampshire, peter.erickson@unh.edu \\ Rosemarie G. Cabral Ph.D. \\ University of New Hampshire - Main Campus \\ Colleen E. Chapman MS \\ University of New Hampshire - Main Campus \\ E. J. Kent \\ University of New Hampshire
}

Follow this and additional works at: https://scholars.unh.edu/biosci_facpub

Part of the Dairy Science Commons

\begin{abstract}
Recommended Citation
Erickson, Peter S.; Cabral, Rosemarie G. Ph.D.; Chapman, Colleen E. MS; and Kent, E. J., "Estimating plasma volume in neonatal Holstein calves fed one or two feedings of a lacteal-based colostrum replacer using Evans blue dye and hematocrit values at various time points." (2015). Canadian Journal of Animal Science. 39.

https://scholars.unh.edu/biosci_facpub/39
\end{abstract}

This Article is brought to you for free and open access by the Biological Sciences at University of New Hampshire Scholars' Repository. It has been accepted for inclusion in Biological Sciences Scholarship by an authorized administrator of University of New Hampshire Scholars' Repository. For more information, please contact Scholarly.Communication@unh.edu. 
1 Estimating plasma volume in neonatal Holstein calves fed one or two feedings of a lactealbased colostrum replacer using Evans blue dye and hematocrit values at various time

3 points.

4

5

6

7 Rosemarie G. Cabral ${ }^{1}$, Colleen E. Chapman, Emily J. Kent, and Peter S. Erickson*

8 Department of Biological Sciences, University of New Hampshire, Durham, 03824, USA

9

10

$11{ }^{*}$ Corresponding author. Tel.: +1 603862 1909:

12 Email address: peter.erickson@unh.edu

1330 O'Kane Road

14 University of New Hampshire

15 Durham, NH, 03824, USA

16

$17{ }^{1}$ Present Address: Famo Feeds, Freeport, MN, USA

18

19

20

21

22

23 
ABSTRACT

25 Twenty-eight Holstein calves were blocked by birth date and randomly assigned to one of two 26 treatments to investigate the effect of colostrum replacer $(\mathbf{C R})$ feeding regimen on plasma 27 volume (PV). Treatments were: 1) one feeding of CR $\left(\mathbf{C}_{\mathbf{1}} ; 3 \mathrm{~L}\right.$ of reconstituted CR $675 \mathrm{~g}$ of 28 powder providing $184.5 \mathrm{~g}$ of $\mathrm{IgG}$ at birth) or 2) two feedings of CR $\left(\mathbf{C}_{2} ; 2 \mathrm{~L}\right.$ of reconstituted CR 29 at birth and $1 \mathrm{~L}$ of reconstituted $\mathrm{CR}$ at six h). By $6 \mathrm{~h}$ of age, all calves had received 3L of CR 30 providing $184.5 \mathrm{~g}$ of IgG. Plasma volume was estimated at six, 12, 18, and $24 \mathrm{~h}$ after birth using 31 Evans blue dye (EBD). No treatment effects were noted at any time points $(P>0.05)$. Mean PV

32 for all calves regardless of treatment at six, 12,18 , and $24 \mathrm{~h}$ were $78.6,89.2,83.9$, and $90.7 \mathrm{~mL}$ $33 \mathrm{~kg}^{-1}$ of BW, respectively. Plasma volume was correlated with hematocrit (HCT), initial HCT, 34 and treatment. Hematocrit was correlated with PV, initial HCT, and body weight. Hematocrit for 35 six, 12, 18 and $24 \mathrm{~h}$ after birth can be predicted with an initial precolostral HCT determination.

\section{RÉSUMÉ}

38 Vingt-huit veaux de race Holstein ont été classés par leurs dates de naissance et soumis

39 aléatoirement à l'un de deux traitements afin d'examiner l'effet d'un régime alimentaire de

40 remplacement de colostrum (RC) sur le volume plasmatique (VP). Les traitements étaient : 1)

41 Un dosage de $\mathrm{RC}\left(\mathbf{C}_{\mathbf{1}} ; 184,5 \mathrm{~g}\right.$ de $\mathrm{IgG}$ à la naissance) ou 2$)$ deux dosages de $\mathrm{RC}\left(\mathbf{C}_{\mathbf{2}} ; 2 / 3\right.$ de la

42 dose totale à la naissance, $1 / 3$ de la dose totale 6 heures plus tard). Le volume plasmatique a été

43 estimé six, douze, dix-huit et vingt-quatre heures après la naissance. Le colorant bleu d'Evans

44 (CBE) a été utilisé pour estimer le VP; l'effet du traitement n'a été observé à aucun moment sur 45 le VP $(P>0,05)$. Indépendamment du traitement, les moyennes de VP pour tous les veaux à six, 46 douze, dix-huit et vingt-quatre heures étaient 78,6;89,2;83,9 et 90,7 $\mathrm{mL} \mathrm{kg}^{1}$ de poids corporel 
47 (PC), respectivement. Le VP a été corrélé à l'hématocrite (HtC), l'HtC initial et au traitement.

48 L'hématocrite a été corrélé au VP, à l'HtC initial et au poids. L'hématocrite à six, douze, dix-

49 huit et vingt-quatre heures après la naissance peut-être prédit par une détermination initiale de

$50 \quad 1^{\prime} \mathrm{HtC}$ avant l'ingestion de colostrum.

51

52 Key words: calf, plasma volume, colostrum replacer, hematocrit

54 Abbreviations: AEA, apparent efficiency of absorption; CR, colostrum replacer; EBD Evans

55 Blue Dye; HCT hematocrit; I $\mu \mathrm{g}$ of dye injected; IgG immunoglobulin G; PV plasma volume; $\mathbf{S}$

56 absorbance of standard; $\mathbf{U}$ absorbance of unknown

57

58

59

60

61

62

63

64

65

66

67

68

69 


\section{INTRODUCTION}

71 Apparent efficiency of absorption (AEA) is commonly calculated in neonatal calf research as

72 another means of viewing Immunoglobulin G (IgG) absorptive data. The AEA can be estimated

73 using the equation: [plasma $\operatorname{IgG}(\mathrm{g} / \mathrm{L}) \times \mathrm{BW}(\mathrm{kg}) \times 0.09 / \operatorname{IgG}$ mass consumed $(\mathrm{g})]$ x $100 \%$

74 (Quigley et al., 1998). Within the equation, the value 0.09 refers to PV, which has been measured

75 in the calf at 24 and $48 \mathrm{~h}$ of age. Prior to the work of Quigley et al. (1998), Mollenberg et al.

76 (1975) reported PV increasing from $53 \mathrm{~mL}$ (plasma) $\mathrm{kg}^{-1}$ of BW at birth to $65 \mathrm{ml} \mathrm{kg}^{-1}$ of BW at

77 one day old after being fed $150 \mathrm{~g}$ of colostrum $\mathrm{kg}^{-1}$ of BW in four feedings and McEwan et al.

78 (1968) indicated that PV increased from $66 \mathrm{ml} \mathrm{kg}^{-1}$ of BW at birth to $93 \mathrm{ml} \mathrm{kg}^{-1}$ of BW at the end

79 of d one after calves were fed colostrum. Quigley et al. (1998) attributed the discrepancies in PV

80 values in the aforementioned studies to the small number of calves used. These data are also

81 limited by PV being measured only at birth and $24 \mathrm{~h}$ after birth. Researchers feeding CR utilize

82 the equation of Quigley et al. (1998). However, that equation was derived from calves fed

83 colostrum. Most researchers studying colostrum feed calves 4L while adequate passive transfer

84 can occur in calves fed $3 \mathrm{~L}$ of CR. Therefore, we question the appropriateness of using the

85 equation of Quigley et al. (1998) for calves fed CR. An objective of this study was to provide

86 PV of calves fed CR for the determination of AEA at different time points such as six, 12, and 18

$87 \mathrm{~h}$ after birth.. The second objective of this experiment was to determine if there were differences

88 in PV due to feeding regimen of CR using EBD at six, 12, 18, and $24 \mathrm{~h}$ after birth in Holstein

89 dairy calves. The third objective was to determine PV at different time points and to determine if

90 there was any correlation between HCT values and PV determined by the EBD procedure. If

91 HCT values are correlated with PV, then it is possible that PV could be calculated on a per calf 
92 basis using HCT values at each time point. The last objective of this study was to determine if

93 HCT could be predicted using precolostral HCT values.

\section{MATERIALS AND METHODS}

\section{Experimental Design and Treatment Diets}

Institutional Animal Care and Use Committee (\# 111205 and 130105).

$$
\text { This experiment was reviewed and approved by the University of New Hampshire }
$$
their navels dipped with a $7 \%$ tincture of iodine. Calves were individually housed for the duration of the experiment. All calves received 3 sachets of Calf's Choice Total ${ }^{\mathrm{TM}}$ Gold CR containing a total IgG mass of $184.5 \mathrm{~g}$ reconstituted, according to manufacturer's instructiona to

103 a final volume of 3L (The Saskatoon Colostrum Co., Saskatoon, SK). One sachet of product 104 contains $225 \mathrm{~g}$ of powder. Therefore, all calves received $675 \mathrm{~g}$ of powder. Assuming $950 \mathrm{~g} \mathrm{~kg}^{-1}$ 105 (DM) each calf received $641 \mathrm{~g}$ of solids with a final volume of $3 \mathrm{~L}$. Total solids equaled 210 $106 \mathrm{~g} / \mathrm{L}$. Calves were assigned to one of two treatments: 1$)$ one feeding of $\mathrm{CR}\left(\mathrm{C}_{1}\right)$ or 2$)$ two feedings 107 of $\mathrm{CR}\left(\mathrm{C}_{2}\right)$. Calves fed a single feeding of CR received the total dose at $0 \mathrm{~h}(3 \mathrm{~L} \mathrm{CR}, 184.5 \mathrm{~g}$ $108 \mathrm{IgG})$. Calves assigned to two feedings received $2 / 3$ of the total $\mathrm{CR}$ dose at $0 \mathrm{~h}$ (2L CR, $123 \mathrm{~g}$ $109 \mathrm{IgG})$ and the remaining $1 / 3$ of $\mathrm{CR}$ at six h (1L CR, $61.5 \mathrm{~g} \mathrm{IgG})$. All calves had consumed $3 \mathrm{~L}$ of

110 CR by six h. Calves were fed via nipple bottle with the first feeding of CR given at $0 \mathrm{~h}$ (within $11130 \mathrm{~min}$ of birth). If the calf did not consume the entire volume of CR, it was administered via 112 esophageal tube to ensure the total dose was received. 


\section{Evans Blue Dye Procedure}

Blood samples for PV analysis were collected at six, 12, 18, and $24 \mathrm{~h}$ of age. The stock

118 solution of EBD was prepared by weighing $2 \mathrm{~g}$ of $750 \mathrm{~g} \mathrm{~kg}^{-1} \mathrm{EBD}$ into a volumetric flask mixed

119 with $100 \mathrm{~mL}$ of $9 \mathrm{~g} \mathrm{~L}^{-1}$ sterile $\mathrm{NaCl}$ and stored at $3^{\circ} \mathrm{C}$. At all sampling times, $10 \mathrm{~mL}$ of blood was

120 collected into Vacutainer tubes containing freeze-dried Na-heparin (Kendall, Mansfield, MA,

121 USA) via jugular venipuncture using a 22-gauge needle. After the pre-injection blood sample

122 was collected, approximately $1.5 \mathrm{~mL}$ of stock solution was injected into the jugular vein. The

123 syringe was weighed prior to and after injection so exact amount of dye administered was

124 known. After injection, the dye was allowed to equilibrate for $10 \mathrm{~min}$ before a post-injection

125 blood sample was obtained into $10 \mathrm{~mL}$ Na-heparinized Vacutainer tubes. Blood samples were 126 centrifuged (CentraMP4R; International Equipment Company; Needham HTS, MA, USA) at

$1271,310 \times g$ at $-4^{\circ} \mathrm{C}$ for $20 \mathrm{~min}$ (within $15 \mathrm{~min}$ of collection). The plasma was harvested and stored 128 at $-20^{\circ} \mathrm{C}$ until PV analysis via spectrophotometry. Absorbance of the spectrophotometer

129 (Beckman DU 520; Brea, CA, USA) was set to $620 \mathrm{~nm}$. Upon analysis, plasma samples were 130 thawed and $1 \mathrm{~mL}$ of pre-injection plasma was transferred into a cuvette and the

131 spectrophotometer was blanked against the sample. Fifty $\mu 1$ of standard dye solution (prepared

132 by adding $1 \mathrm{~mL}$ of stock solution to a $100-\mathrm{mL}$ volumetric flask which was diluted with $9 \mathrm{~g} \mathrm{~L}^{-1}$

$133 \mathrm{NaCl}$ solution) was added to the plasma blank, vortexed and absorbance read. Finally,

134 absorbance of the post-injection sample was obtained. The PV was calculated using the equation:

$135[1 /((\mathrm{U} \div \mathrm{S}) \times 7.142857)] \times \mathrm{I}$, where $\mathrm{U}=$ absorbance of unknown (post-injection sample); $\mathrm{S}=$

136 absorbance of standard (pre-injection sample $+50 \mu \mathrm{l}$ of standard dye solution); and $\mathrm{I}=\mu \mathrm{g}$ of dye 137 injected (mL of stock injected $\times 15 \mathrm{mg}$ dye $\mathrm{mL}^{-1}$ stock $\left.\times 1000\right), 7.142857$ is equal to the amount 
138 of dye in the standard plasma sample ( $50 \mu \mathrm{L}$ of dye containing $0.15 \mathrm{mg}$ dye $\mathrm{mL}^{-1}$ of standard 139 dye solution added to $1 \mathrm{~mL}$ of plasma $=7.5 \mu \mathrm{g} \div 1.05 \mathrm{~mL}$ ).

\section{Blood Collection for Hematocrit}

A subsample of blood collected for PV analysis was obtained for evaluation of packed cell volume. An initial sample was obtained at birth before CR feeding for HCT analysis as well.

144 Capillary tubes were centrifuged (Haematokrit 210; Andreas Hettich GmBH \& Co; Germany) at $14516,060 \times \mathrm{g}$ at $25^{\circ} \mathrm{C}$ for $5 \mathrm{~min}$.

\section{Statistical Analysis} block design according to the following model:

$$
\begin{aligned}
& \mathrm{Y}_{\mathrm{ijk}}=\mu \mathrm{B}_{\mathrm{i}}+\mathrm{C}_{\mathrm{j}}+\mathrm{H}_{\mathrm{k}}+\mathrm{E}_{\mathrm{ijk}} \\
& \text { Where: } \\
& \mathrm{Y}=\text { the dependent variable; } \mu=\text { the overall mean; } \\
& \mathrm{B}_{\mathrm{i}}=\text { the random effect of block } \mathrm{i}(\mathrm{i}=1, \ldots 14) ; \\
& \mathrm{C}_{\mathrm{j}}=\text { the fixed effect of the } \mathrm{j}^{\text {th }} \mathrm{CR} \text { feeding regimen }(\mathrm{k}=1,2) ; \\
& \mathrm{H}_{\mathrm{k}}=\text { the fixed effect of the } \mathrm{k}^{\text {th }} \text { hour }(\mathrm{k}=6,12,18, \text { and } 24) ; \\
& \mathrm{E}_{\mathrm{ij}}=\text { the residual error } \sim \mathrm{N}\left(\mathrm{O}_{1} \sigma^{2} \mathrm{e}\right) .
\end{aligned}
$$

Degrees of freedom were calculated using the Kenward-Rogers option of the MIXED procedure of SAS ${ }^{\circledR}$ (Version 9.3; SAS Institute, Inc. Cary, NC, USA). Least square means were

161 determined for each treatment. Significant treatment effects were noted at $P \leq 0.05$ and trends

162 were noted at $0.05<P \leq 0.10$. Regression analysis was conducted using the regression procedure 163 of SAS using PV $\left(\mathrm{g} \mathrm{kg}^{-1} \mathrm{BW}\right)$ and $\mathrm{HCT}$. Variables used in the regression analysis for PV were:

164 sex, HCT, initial HCT, BW and treatment. Variables used in the regression analysis for HCT 
165 were: sex, initial HCT, BW, treatment, hour (for overall value), and PV (mL). Correlation

166 coefficients were determined using the correlation procedure of SAS (Version 9.3; SAS Institute,

167 Inc., Cary NC, USA),

168

Results

Mean BW was $46 \pm 4.61 \mathrm{~kg}$, mean initial HCT was $39.4 \pm 6.82 \%$, mean $\mathrm{HCT}$ was $35.2 \pm$

$1715.83 \%$, and mean PV was 3,866 $2022 \mathrm{~mL}$ (Tables 1 and 2). Three calves on the $\mathrm{C}_{1}$ and two

172 calves on $\mathrm{C}_{2}$ treatment groups were fed using an esophageal tube feeder. The calves on treatment

$173 \mathrm{C}_{1}$ required all of the $\mathrm{CR}$ to be fed in this manner. Whereas, one calf on $\mathrm{C}_{2}$ required all of the CR

174 fed in this manner while the other calf consumed its first feeding via nipple bottle, but was fed

175 the total six h dose with the esophageal feeder. Initially, 28 samples per time point were

176 obtained; however, due to sampling error or hemolysis, 4 calves were removed from analysis (2

177 per treatment). Analyses of $\mathrm{PV}\left(\mathrm{mL}\right.$, and $\mathrm{mL} \mathrm{kg}^{-1}$ of $\left.\mathrm{BW}\right)$ along with $\mathrm{HCT}$ data are presented in

178 Table 1. Mean PV for all calves regardless of treatment at six, 12, 18, and $24 \mathrm{~h}$ were 78.2, 89.2,

17983.9 , and $90.7 \mathrm{~mL} \mathrm{~kg}^{-1}$ of BW, respectively. Treatment did not affect PV expressed as either mL

180 or $\mathrm{mL} \mathrm{kg}^{-1}$ of BW at any time point (Table 1). Hematocrit did not vary at any time point (Table

181 1). Mean, minimum and maximum values for PV, BW, initial HCT and HCT are in Table 2.

182 Correlation coefficients (Table 3) for PV showed strong relationships between PV, HCT, initial

183 HCT and treatment. Prediction equations for PV as a percent of BW had coefficients of multiple

184 determinations $\left(\mathrm{r}^{2}\right)$ values that ranged from 0.19 for the $12 \mathrm{~h}$ prediction equation to 0.32 for the

1856 h equation suggesting a weak relationship (Table 4).

186 Prediction equations for HCT had $\mathrm{r}^{2}$ values that ranged from 0.69 for the $6 \mathrm{~h}$ equation to

1870.84 for the $24 \mathrm{~h}$ equation (Table 5. Body weight and initial HCT can be used to predict HCT at 
18812 and $24 \mathrm{~h}$. Whereas, these variables plus sex of the calf can predict HCT at six and $18 \mathrm{~h}$ 189 (Figure 1).

Evans blue dye has been used as a marker of PV in cattle (Dalton and Fisher, 1961;;

192 Payne et al., 1967; Möllenberg et al., 1975; Thornton and English, 1978; Besser and Osborn,

1931993 ), sheep (English, 1966; Mackie, 1976; van Waversveld and van Bruchem, 1985), horses

194 (McKeever et al., 1988), and pigs (McCance and Widdowson, 1959). Estimates of PV using

195 EBD and other methods typically indicate close correlation; however, van Waversveld and van 196 Brushem (1985) reported that EBD estimated total blood volume but not PV. However a strong 197 correlation was found between PV and hematocrit $(\mathrm{P}=0.006)$. Quigley et al. (1998), with 146 198 calves sampled, also reported large variability in PV among calves even with the same BW (39 $199 \mathrm{~kg}$ ) with PV as $\mathrm{mL} \mathrm{kg}^{-1}$ of BW ranging from $60-131$. This is similar to calves used on the 200 current study with a BW of $40 \mathrm{~kg}$ having PV ranging from $67-131$.

201 Research in human physiology has indicated that PV can be estimated by using a 202 patient's height, weight, and HCT; however, equations are only reliable at normal HCT. 203 Sprenger et al. (1987) were able to modify equations and allow for accurate calculation of PV 204 even with the use of pathological HCT but PV was measured using 51CR-method and not EBD. 205 Quigley et al. (1998) reported that birth BW was the best predictor of PV, though the relationship 206 was not linear; however, multiple regression analysis using HCT and BW yielded no correlation 207 with PV. Our results may have been affected by the use of EBD and perhaps a more accurate 208 method of PV estimation should be used in the future.

209 There was no difference in PV between treatments across the 4 sampling times.

210 Regardless of treatment, mean PV for all calves at six, 12, 18, and $24 \mathrm{~h}$ were 78.2, 89.2, 83.9 
$21190.7 \mathrm{~mL} \mathrm{~kg}^{-1}$ of BW, respectively. Quigley et al. (1998) reported PV at $24 \mathrm{~h}$ at $98.6 \mathrm{~mL} \mathrm{~kg}^{-1}$ of

212 BW. The authors also adjusted for loss of EBD from plasma caused by single-point sampling by

213 multiplying PV as $\mathrm{mL} \mathrm{kg}^{-1}$ of BW by 9.06 (correction factor determined as the mean

214 overestimations reported by Mackie (1976) and Möllenberg et al. (1975)), which resulted in a

215 new mean PV of $89 \mathrm{~mL} \mathrm{~kg}^{-1}$ of BW. Adjusting PV at $24 \mathrm{~h}$ by this same method reduces our

216 estimate of PV to $82.5 \mathrm{~mL} \mathrm{~kg}^{-1}$ of BW. Adjusting for EBD loss at six, 12 and $18 \mathrm{~h}$ results in

217 new PV values of : 71.1, 81.1, $76.3 \mathrm{ml} \mathrm{kg}^{-1}$. Quigley et al. (1998) also indicate that age at

218 sampling averaged $24.3 \mathrm{~h}$ but ranged from $22.75-28.75 \mathrm{~h}$. All calves used in the current study

219 had samples obtained within $\pm 15 \mathrm{~min}$ from designated time point ( $\operatorname{six} 12,18$, or $24 \mathrm{~h}$ ). The

220 differences in sampling time may have impacted PV values. Colostrum intake type and volume

221 (3L of CR vs, 1.5-4L colostrum) were also inconsistent between studies. The current study

222 utilized CR with esophageal tube feeding used to ensure the total volume of CR was consumed.

223 Quigley et al. (1998) utilized colostrum with intake averaging 3.76 L but ranging from 1.50 -

224 4.00 L. Differences in volume of colostrum consumed may have affected hydration status and, 225 therefore, PV of their calves.

226 Calves on the current study were also sampled at four total time points, as compared to

227 one time point in the previously mentioned study. This may have affected the integrity of the

228 blood vessel leading to an increase in loss of EBD during the equilibration period. Samples

229 obtained at six, $12,18 \mathrm{~h}$ and $24 \mathrm{~h}$ may have been slightly inaccurate because of the rate of loss of

230 EBD from circulation. Younger animals lose EBD from circulation more rapidly than older

231 animals (Thornton and English, 1978). By 24 h of age, calves were more apt to struggle during

232 administration of dye and blood sampling. This may have increased EBD loss from circulation

233 therefore adding to sample inaccuracy. 
Results from this experiment provide researchers with values to allow determination of

235 AEA when CR is fed. Also, determination of AEA at different time points over the first $24 \mathrm{~h}$ of

236 life which will allow for a more accurate determination of when IgG absorption is maximized.

237 Hematocrit was not different between treatments. Hematocrit is a measure of packed cell

238 volume, which is an indicator of hydration status. Though the total volume was identical,

239 spreading the feeding between 2 time periods may have affected hydration status. Overall, HCT

240 decreased from birth to $24 \mathrm{~h}$ indicating an increase in hydration status. Hematocrit, sex,

241 treatment and initial HCT were correlated with PV in this study. Initial BW, sex and precolostral

242 HCT can be used to predict HCT at six,12, 18 and $24 \mathrm{~h}$ after birth in Holstein calves receiving

243 CR.

measurements. Plasma volume was highly correlated to sex, HCT, initial HCT and feeding

247 regimen. Prediction equations to determine PV utilizing BW, sex, feeding regimen, initial HCT

248 and HCT had correlation coefficients that ranged from 0.25 to 0.40 indicating a weak

249 relationship. However, a better relationship was found for predicting HCT with $\mathrm{r}^{2}$ ranging from

$250 \quad 0.69$ to 0.84 . An initial precolostral blood sample along with BW can accurately predict HCT at

251 12, and $24 \mathrm{~h}$. Those values along with an adjustment for sex of the calf can accurately predict

252 hematocrit at six and $18 \mathrm{~h}$ after birth. Researchers evaluating CR can utilize these data to

253 accurately determine AEA and pinpoint when IgG absorption is maximized.. 
259 authors would like to thank the staff of the Fairchild Teaching and Research Center (University

260 of New Hampshire) for the use of calves and their assistance throughout the study and Dr.

261 Nadine Berenguier, Professor of French, Department of Languages, Literatures and Cultures

262 (University of New Hampshire) for translating the abstract. Partial funding was provided by the

263 New Hampshire Agricultural Experiment Station. This is Scientific Contribution number 2544. 
284 Besser, T. E. and Osborn, D.. 1993. Effect of bovine serum albumin on passive transfer of 285 immunoglobulin G1 to newborn calves. Vet. Immunol. Immunopathol. 37:321-327.

286 Dalton, R. G., and Fisher, E.W.. 1961. Plasma and blood volumes in Ayrshire cattle. Br. Vet. J. $287 \quad 117: 115-119$.

288 English, P. B. 1966. A study of water and electrolyte metabolism in sheep. II. The volumes of 289 distribution of antipyrine, thiosulfate, and T1824 (Evans blue) and values for certain extracellular fluid constituents. Res. Vet. Sci. 7:258-275.

Mackie, W. S. 1976. Plasma volume measurements in sheep using Evans' blue and continuous blood sampling. Res. Vet. Sci. 21:108-109.

McCance, R. A. and Widdowson, E.M.. 1959. The effect of colostrum on the composition and volume of the plasma of new-born piglets. J. Physiol. 145:547-550.

McEwen, S. A., Martin, W., Clarke, R.C.,and Tamblyn, S.E.. 1988. A prevalence survey of Salmonella in raw milk in Ontario, 1986- 87. J. Food Prot. 51:963-965.

McKeever, K. H. Schurg, W.A.,and Convertino, V.A.. 1988. A modified Evans blue dye method for determining plasma volume in the horse. Equine Vet. Sci. 8:208-212.

Möllerberg, L., Ekman, L., and Jacobsson, S.. 1975. Plasma and blood volume in the calf from birth till 90 days of age. Acta. Vet. Scand. 16:178-185.

Payne, E., Ryley, J.W., and Gartner, R.J.W. 1967. Plasma, blood, and extracellular fluid in grazing Hereford cattle. Res. Vet. Sci. 8:20-26.

Quigley, J. D. III, Drewry, J.J.,and Martin, K.R.. 1998. Estimation of plasma volume in Holstein and Jersey calves. J. Dairy Sci. 81:1308-1312.

Sprenger, K. B., Huber, K., Kratz,W., and Henze, E.. 1987. Nomograms for the prediction of patient's plasma volume in plasma exchange therapy from height, weight, and hematocrit. J. Clin. Apher. 3:185-190.

Thornton, J. R. and English, P.B.,. 1978. Body water of calves: Change in distribution with diarrhoea. Br. Vet. J. 134: 445-453.

Van Waversveld, J. and van Bruchem, J. 1985. Estimation of blood (plasma) volume in sheep with Evans blue and bromsulphalein. Neth. J. Agric. Sci. 33:325-327. 
314 Table 1. Calves, body weight, plasma volume and hematocrit for calves fed colostrum replacer

315 either all at birth or split between two feedings.

\begin{tabular}{|c|c|c|c|}
\hline & & Treatement $^{1}$ & \\
\hline Item & $\mathrm{C}_{1}$ & $\mathrm{C}_{2}$ & $\mathrm{SE}^{2}$ \\
\hline $\mathrm{BW}, \mathrm{kg}(+/-\mathrm{SD})$ & $44.90+/-4.0$ & $46.70+/-5.1$ & \\
\hline Initial HCT, \% & $38.25+/-3.36$ & $41.09+/-3.50$ & \\
\hline $\mathrm{PV}^{3}, 6 \mathrm{~h}, \mathrm{~mL}$ & 3,522 & 3,590 & 289 \\
\hline $\mathrm{PV}, 12 \mathrm{~h}, \mathrm{~mL}$ & 3,612 & 3,967 & 289 \\
\hline $\mathrm{PV}, 18 \mathrm{~h}, \mathrm{~mL}$ & 3,221 & 4,376 & 289 \\
\hline $\mathrm{PV}, 24 \mathrm{~h}, \mathrm{~mL}$ & 3542 & 3,615 & 289 \\
\hline $\mathrm{PV}, 6 \mathrm{~h}, \mathrm{~mL} \mathrm{~kg}^{-1} \mathrm{BW}$ & 78.5 & 78.7 & 8.2 \\
\hline $\mathrm{PV}, 12 \mathrm{~h}, \mathrm{~mL} \mathrm{~kg}^{-1} \quad \mathrm{BW}$ & 90.2 & 88.2 & 8.2 \\
\hline $\mathrm{PV}, 18 \mathrm{~h}, \mathrm{~mL} \mathrm{~kg}^{-1}, \mathrm{BW}$ & 80.0 & 87.9 & 8.2 \\
\hline $\mathrm{PV}, 24 \mathrm{~h}, \mathrm{~mL} \mathrm{~kg}^{-1} \mathrm{BW}$ & 81.4 & 100.0 & 8.2 \\
\hline $\mathrm{HCT}^{5}, 6 \mathrm{~h}, \%$ & 36.8 & 38.0 & 1.3 \\
\hline $\mathrm{HCT}, 12 \mathrm{~h}, \%$ & 34.3 & 35.1 & 1.3 \\
\hline HCT, $18 \mathrm{~h}, \%$ & 33.8 & 35.4 & 1.3 \\
\hline HCT, $24 \mathrm{~h}, \%$ & 34.2 & 35.0 & 1.3 \\
\hline \multicolumn{4}{|c|}{${ }^{1}$ Treatment $C_{1}=$ all colostrum replacer is fed at time $0 \mathrm{~h}, \mathrm{C}_{2}=$ colostrum replacer fed $2 / 3$ at time } \\
\hline \multicolumn{4}{|l|}{$0 \mathrm{~h}$ and $1 / 3$ at $6 \mathrm{~h}$. } \\
\hline \multicolumn{4}{|l|}{${ }^{2}$ Standard error. } \\
\hline${ }^{3}$ Repeated measures by ho & or plasma volume ( & was not different & $<0.13)$ \\
\hline
\end{tabular}

$317 \overline{{ }^{1}}$ Treatment $\mathrm{C}_{1}=$ all colostrum replacer is fed at time $0 \mathrm{~h}, \mathrm{C}_{2}=$ colostrum replacer fed $2 / 3$ at time

$3180 \mathrm{~h}$ and $1 / 3$ at $6 \mathrm{~h}$.

$319{ }^{2}$ Standard error.

$320{ }^{3}$ Repeated measures by hour for plasma volume $(\mathrm{mL})$ was not different $(\mathrm{P}<0.13)$.

$321{ }^{4}$ Repeated measures by hour for plasma volume ( $\%$ of body weight) was not different $(\mathrm{P}=0.54)$. 
$322{ }^{5}$ Repeated measures by hour for hematocrit was not different $(\mathrm{P}=0.99)$.

323

324

325

326

327

328

329

330

331

332

333

334

335

336

337

338

339

340

341

342

343

344 
345 Table 2. Mean, minimum and maximum values and standard deviations for data used in

346 development of prediction equations.

\begin{tabular}{lrrrrc}
\hline Variable & $\mathrm{n}$ & \multicolumn{1}{l}{ Mean } & $\mathrm{SD}$ & Minimum & Maximum \\
\hline $\mathrm{PV}, \mathrm{mL}$ & 95 & 3,430 & 1,333 & 1376 & 7176 \\
$\mathrm{BW}, \mathrm{kg}$ & 97 & 45.87 & 4.68 & 40.0 & 56.0 \\
Initial HCT, \% & 97 & 39.63 & 6.90 & 24.0 & 54.0 \\
HCT, \% & 94 & 35.37 & 5.78 & 20.0 & 45.0 \\
\hline
\end{tabular}


362 Table 3. Correlation coefficients for plasma volume, sex, body weight, hematocrit, initial

363 hematocrit, and treatment.

\begin{tabular}{|c|c|c|c|c|c|c|}
\hline Item & $\mathrm{PV}^{1}(\mathrm{~mL})$ & Sex & $\mathrm{BW}^{2}$ & $\mathrm{HCT}^{3}$ & $\mathrm{Hi}^{4}$ & $\operatorname{Trt}^{5}$ \\
\hline \multirow[t]{2}{*}{ PV (mL) } & 1.000 & 0.03 & -0.12 & -0.21 & -0.26 & 0.13 \\
\hline & & $\mathrm{P}=0.74$ & $\mathrm{P}=0.28$ & $\mathrm{P}=0.06$ & $\mathrm{P}=0.02$ & $\mathrm{P}=0.24$ \\
\hline \multirow[t]{2}{*}{ Sex } & & 1.000 & -0.51 & -0.01 & 0.07 & -0.08 \\
\hline & & & $\mathrm{P}<0.0001$ & $\mathrm{P}=0.92$ & $\mathrm{P}=0.49$ & $\mathrm{P}=0.39$ \\
\hline \multirow[t]{2}{*}{ BW } & & & 1.000 & 0.33 & 0.09 & 0.20 \\
\hline & & & & $\mathrm{P}=0.0005$ & $\mathrm{P}=0.38$ & $\mathrm{P}=0.04$ \\
\hline \multirow[t]{2}{*}{ HCT } & & & & 1.000 & 0.81 & 0.08 \\
\hline & & & & & $\mathrm{P}<0.0001$ & $\mathrm{P}=0.41$ \\
\hline \multirow[t]{2}{*}{$\mathrm{Hi}$} & & & & & 1.000 & 0.06 \\
\hline & & & & & & $\mathrm{P}=0.51$ \\
\hline Trt & & & & & & 1.000 \\
\hline
\end{tabular}

364

$365{ }^{1}$ Plasma volume in $\mathrm{mL}$.

$366{ }^{2}$ Body weight.

$367{ }^{3}$ Hematocrit.

$368{ }^{4}$ Initial Hematocrit.

$369{ }^{5}$ Treatment- feeding regimen (one feeding of CR or 2 feedings of CR).

370

371 
372 Table 4. Prediction equations for plasma volume ( $\%$ of BW) at various time points ${ }^{1}$.

\begin{tabular}{|c|c|c|c|c|c|c|c|}
\hline Hour $^{2}$ & Intercept & $\operatorname{Sex}^{3}$ & $\begin{array}{l}\mathrm{BW}^{4} \\
\mathrm{~kg}\end{array}$ & $\begin{array}{l}\text { Initial } \mathrm{HCT}^{5} \\
\%\end{array}$ & $\mathrm{HCT}^{6}$ & $\operatorname{Trt}^{7}$ & $r^{2}$ \\
\hline 6 & 21.80 & - & -0.28 & -0.11 & - & 1.66 & 0.32 \\
\hline 12 & 19.93 & - & - & -0.29 & - & & 0.19 \\
\hline 18 & 14.38 & 2.51 & - & - & -0.28 & - & 0.22 \\
\hline 24 & 11.58 & 2.80 & - & - & -0.31 & 2.56 & 0.31 \\
\hline
\end{tabular}

$373{ }^{\mathrm{I}}$ Variables with blank spaces indicate that $\mathrm{P}>/=0.25$.

$374 \quad{ }^{2}$ Hour corresponds to time after birth.

$375 \quad{ }^{3}$ Sex, $1=$ bull, $2=$ heifer.

$376 \quad{ }^{4}$ Body weight.

$377 \quad{ }^{5}$ Initial Hematocrit.

$378 \quad{ }^{6}$ Hematocrit.

$379{ }^{7}$ Treatment $1=$ fed at $0 \mathrm{~h}, 2=$ fed in 2 feedings. 
389 Table 5. Prediction equations for hematocrit ${ }^{1}$

\begin{tabular}{llllll}
\hline Hour & Intercept & $\mathrm{Sex}^{2}$ & $\mathrm{BW}^{3}, \mathrm{~kg}$ & $\begin{array}{l}\text { Initial HCT, } \\
\%\end{array}$ & $\mathrm{r}^{2}$ \\
& & & & & \\
\hline 6 & -3.74 & 2.05 & 0.33 & 0.58 & 0.69 \\
& & & & & \\
12 & -2.59 & - & 0.26 & 0.71 & 0.74 \\
18 & -13.7 & 2.08 & 0.43 & 0.64 & 0.77 \\
24 & -12.14 & - & 0.39 & 0.73 & 0.84 \\
\hline
\end{tabular}

$391{ }^{1}$ Variables with blank spaces indicate that $\mathrm{P}>/=0.25$.

392

$393{ }^{2}$ Sex, $1=$ bull, $2=$ heifer.

394

$395 \quad{ }^{3}$ Body weight.

396

397

398

399

400

401

402

403

404

405

406

407

408

409

410 


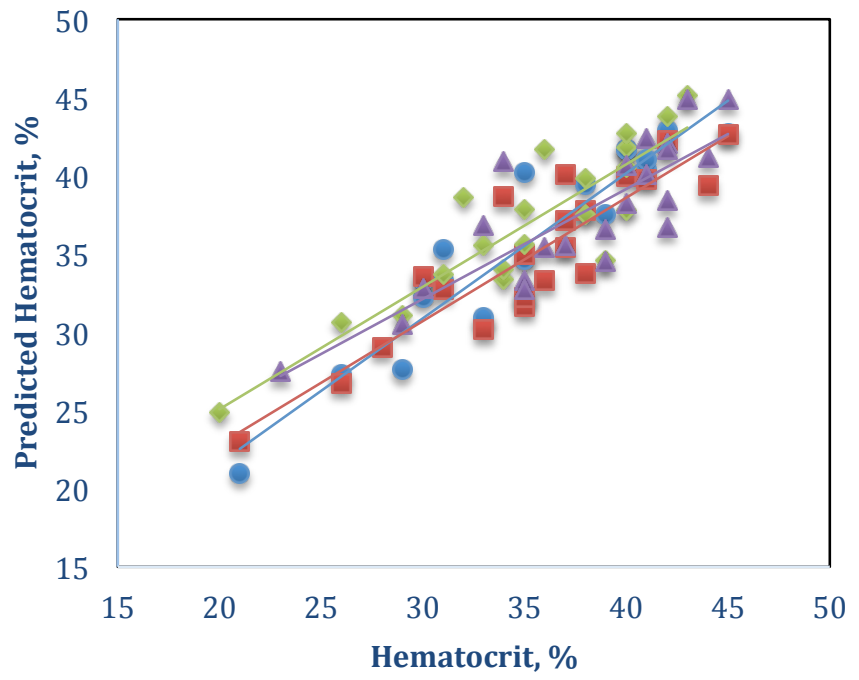

$24 \mathrm{~h}$

- $18 \mathrm{~h}$

- $12 \mathrm{~h}$

$\Delta 6 \mathrm{~h}$

L Linear (24 h)

Linear (18 h)

Linear (12 h)

- Linear (6 h)

411

412

413

414 Figure 1. Predicted hematocrit versus measured hematocrit.

415

416

Cabral et al 